\title{
ОСОБЛИВОСТІ ПЕДАГОГІЧНОГО СПІЛКУВАННЯ В УМОВАХ ВПРОВАДЖЕННЯ БОЛОНСЬКОГО ПРОЦЕСУ У ВИЩОМУ МЕДИЧНОМУ ЗАКЛАДІ
}

\author{
С. І. Шкробот, О. П. Венгер, Т. П. Гусєва
}

ДВНЗ “Тернопільський державний медичний університет

імені І. Я. Горбачевського МОЗ Украӥни”

\section{PECULIARITIES OF PEDAGOGICAL COMMUNICATION IN THE CONDITIONS OF INTRODUCTION OF BOLOGNA PROCESS IN HIGHER MEDICAL INSTITUTION}

\author{
S. I. Shkrobot, O. P. Venher, T. P. Husieva \\ SHEI "Ternopil State Medical University by I. Ya. Horbachevsky of MPH of Ukraine"
}

\begin{abstract}
У статті зроблена спроба показати засоби ефективного педагогічного спілкування, якими користуються викладачі кафедри неврології, психіатрії, наркології та медичної психології ТДМУ імені І. Я. Горбачевського. До таких засобів належать: різні форми лекцій - мультимедійна лекція, проблемна лекція, лекція-конференція; під час проведення практичних занять застосовуються: тренінг комунікативних навичок, інтерактивні групові методи, вільні дискусії.
\end{abstract}

The article deals with an attempt to show the means of effective pedagogical communication that are used by teachers of Department of Neurology, Psychiatry, Narcology and Medical Psychology of TSMU by I. Ya. Horbachevsky. These means consist of different forms of lectures - multimedia lecture, problem lecture, lecture-conference; during practical lessons there are used: training of communicative skills, interactive group methods, free discussions.

Вступ. На сучасному етапі впровадження у вищу школу Болонського процесу важливою складовою професійної діяльності педагога є його ефективна взаємодія зі студентами в ході спільної діяльності, спрямованої на професійне та особистісне формування майбутнього фахівця медичного профілю. У безпосередньому спілкуванні педагога зі студентом здійснюється найголовніше в педагогічній діяльності - вплив особистості на особистість. Питання ефективного спілкування в педагогічному процесі між студентом та викладачем набуває більшої актуальності й $з$ огляду на те, що Болонська система навчання передбачає зменшення аудиторних годин і надання студентам більшої самостійності при опануванні ними навчальних дисциплін.

У більшості психолого-педагогічних досліджень проблема взаємин педагогів і вихованців розглядається, насамперед, у контексті педагогічного спілкування (Г. Атваттер, О. О. Бодальов, В. Г. Казанська, В. А. Кан-Калик, В. Кессель, Я. Л. Коломінський, С. В. Кондратьєва, Н. В. Кузьміна, О. О. Леонтьєв, А. А. Реан, Г. Хібш та ін.). Ще один напрям дослідження взаємин пов' язаний з вивченням міжособист- існих контактів (М. Д. Аванесов, В. А. Галузинський, В. М. Коротов, Р. Л. Лобаревська, Т. Н. Мальковська, А. В. Мудрик, М. М. Обозов, І. В. Страхов та ін.). Починаючи 3 90-х XX століття, взаємини викладачів і студентів стають самостійним об'єктом і предметом наукового пошуку (I. С. Булах, Л. В. Долинська, В. Г. Казанська, С. Б. Коваль, А. В. Котенєва, В. А. Семиченко, Г. К. Радчук) тощо.

Мета статті - виявити особливості засобів ефективного педагогічного спілкування викладачів кафедри неврології, психіатрії, наркології та медичної психології ТДМУ імені І. Я. Горбачевського.

Основна частина. Орієнтація на поліфункціональність спілкування дає змогу педагогу під час заняття створювати умови для обміну ставленнями, переживаннями, забезпечувати співробітництво у студентській групі. При організації взаємодії зі студентами на практичних заняттях викладачами кафедри неврології, психіатрії, наркології та медичної психології використовуються найбільш продуктивні методи навчання: тренінг комунікативних навичок, інтерактивні групові методи, вільні дискусії. Особливістю педагогічного спілкування під час проведення 
практичних занять $є$ індивідуальний підхід до студентів з метою розкриття їх внутрішнього потенціалу. Важливу роль у процесі цієї діяльності відіграє інтелектуальна активність студентів, яка є проявом зацікавленості студентів-медиків навчально-виховним процесом.

Створення певних взаємин між учасниками педагогічного процесу пов'язано з позитивним ставленням до особистості іншої людини, визнанням їі цінності без упереджень, зайвої критичності й схильності до оцінювання, що сприяє кращій реалізації творчого потенціалу кожного студента.

Ефективне педагогічне спілкування, на нашу думку, має поєднувати в собі відкритість, дотримання педагогічного такту; встановлення особистісного контакту, щоб кожен студент відчував зверненість саме до нього; створення ситуацій успіху через схвалення потенційних можливостей студентів.

Однією з форм занять зі студентами-медиками $\epsilon$ лекція. 3 використанням новітніх комп'ютерних технологій та мультимедійних засобів роль спілкування 3 викладачем також змінюється. Але навіть Інтернет та сучасні інформаційні технології не можуть замінити живе спілкування викладача зі студентами. Як показує практика, більшість студентів ще на перших хвилинах лекції робить висновок про викладача як про такого, хто подає інформацію незрозумілою мовою, інша частина спостерігає за тим, як лектор говорить, які помилки допускає, як поводиться. Комусь може бути нецікаво, тому що він швидко зрозумів сказане лектором, комусь складно сприймати інформацію, бо він вже втомився. Тому завдання викладача полягає у подоланні можливих бар'єрів між ним і студентами й опануванні їхньою увагою.

Пошук найбільш оптимальних засобів активізації інтелектуальної діяльності студентів спонукає викладачів кафедри до застосування нових лекційних форм. До них відносяться: проблемна лекція, лекціяконференція. Зокрема, проблемна лекція пов’ язана зі створенням проблемної ситуаціі, коли процес пізнання у студентів наближається до пошукової діяльності: створюється чи задається ситуаційна задача, відбувається мобілізація студентів для участі в дискусії, пошук шляхів вирішення проблеми, покрокове наближення до відкриття істини.
Якщо аудиторія ставиться до викладача як до досить авторитетного джерела інформації, то йому легше керувати увагою аудиторіі. Але викладач сам повинен ставитися до студентів із дружелюбним інтересом, йому повинні бути цікавими їхня оцінка, думка; він має поважати їхні погляди. Досвід викладання показав позитивний вплив залучення студентської аудиторії до спільного обговорення проблеми. Проте слід враховувати, що слухачі можуть бути різні. Деякі, наприклад, заклопотані власним самоствердженням, будуть намагатися якнайчастіше не погоджуватися 3 лектором. Прекрасно, як зазначає Н. Ю. Бутенко, якщо $\epsilon$ почуття гумору, тоді будь-які, навіть досить колючі зауваження і питання можна обернути собі на користь. Серед тих, хто слухає, можуть виявитися люди дуже тривожні й боязкі, а також такі, які можуть навіть відверто спати чи займатися сторонніми справами. Знання цих особливостей студентської аудиторії допомагає викладачу підбирати відповідний стиль спілкування для оптимальної взаємодії з нею.

Серед студентів ТДМУ багато іноземних громадян. При навчанні іноземних студентів викладач повинен будувати педагогічне спілкування, враховуючи ряд факторів: міжкультурний характер спілкування, спілкування викладача зі студентами-іноземцями перших курсів тісно пов'язане з їх адаптацією. Науковцями були виділені такі комунікативні вміння викладачів: вміння вступати в контакт, керувати власними емоціями, особливо при вирішенні конфліктів, вміння створити сприятливу емоційну атмосферу в аудиторії, вміння впливати на іноземних студентів 3 урахуванням їх національної приналежності, вміння зрозуміти мотиви поведінки іноземних студентів при спілкуванні з викладачем.

Висновок. Оскільки педагогічний процес передбачає взаємодію викладача і тих, хто навчається, вміння спілкуватися - одна з обов'язкових умов досягнення педагогічної майстерності. Мистецтво педагогічного спілкування передбачає таку комунікативну поведінку педагога, яка заснована на коректності, вимогливості до себе й студентів, стимулює пізнавальний інтерес, мотивацію процесу навчання, забезпечує створення розвиваючого освітнього середовища та сприятливої педагогічної взаємодії в системі “викладач-студент”. 


\section{Лiтература}

1. Бутенко Н. Ю. Комунікативні процеси у навчанні : підручник / Н. Ю. Бутенко. -К. : КНЕУ, 2004. -383 с.

2. Головаха Е. И. Психология человеческого общения /

Е. И. Головаха. - К. : Политиздат Украины, 1989. - 187 с.

3. Добрович А. Б. Воспитателю о психологии общения /

А. Б. Добрович. - М. : Просвещение, 1987.-205 с.

4. Зязюн И. А. Основы педагогического мастерства /

И. А. Зязюн. - М. : Просвещение, 1989. - 300 с.

5. Каган М. С. Мир общения / М. С. Каган.-М. : Политиздат, 1988. -320 c.

6. Кан-Калик В. А. Учителю о педагогическом общении /
В. А. Кан-Калик. - М. : Просвещение, 1987.-132 с.

7. Леонтьев А. А. Педагогическое общение / А. А. Леонтьев. - М. : Знание, 1975. -45 с.

8. Король В. М. Спілкування в педагогічній діяльності вчителя / В. М. Король // Педагогічна наука : історія, теорія, практика, тенденції розвитку. - 2008. - № 1.

9. Семиченко В. А. Психологія педагогічної діяльності : навч. посібник [для студ. вищих пед. навч. закл.] / В. А. Семиченко. - К. : Вища школа, 2004. -336 с.

10. Соковнин В. М. О природе человеческого общения / В. М. Соковнин. - М. : Знание, 1992. -145 с. 